\title{
KEEFEKTIFAN MODEL CONTEXTUAL TEACHING AND LEARNING (CTL) TERHADAP HASIL BELAJAR MATEMATIKA MATERI PECAHAN
}

\author{
Ahmad Nasirudin ${ }^{1}$, Intan Rahmawati ${ }^{2}$, Suyitno ${ }^{3}$ \\ 1,2,3 Pendidikan Guru Sekolah Dasar Fakultas IImu Pendidikan \\ Universitas PGRI Semarang \\ Email : ahmadnasirudin63@gmail.com
}

\begin{abstract}
Abstrak
Jenis penelitian ini adalah penelitian kuantitatif dengan desain penelitian pre-Eksperimental Design berupa one group pretest-postest design.Penelitian ini bertujuan untuk mengetahui keefektifan model Contextual Teaching and Learning terhadap hasil belajar matematika materi pecahan siswa kelas V SD N 01 Rowosari Kendal. Sampel yang diambil adalah 25 siswa. Berdasarkan perhitungan uji normalitas awal menggunakan uji Liliefors, diperoleh $\mathrm{n}=22$ dan taraf nyata $\alpha=0,05$, dari daftar nilai kritis $L$ didapat $L$ tabel $=0,90$. Karena Lhitung $<$ Ltabel yaitu $0,142<0,190$, maka Ho diterima sehingga dapat disimpulkan bahwa sampel berasal dari populasi berdistribus normal. Berdasarkan hasil perhitungan data akhir nilai posttest diperoleh Lhitung $=0,164$ dengan $n=22$ dan taraf nyata $\alpha=0,05$ dari daftar nilai kritis $L$ didapat Ltabel $=0,190$, karena Lhitung $<$ Ltabel yaitu 0,082 $<0,173$ maka Ho diterima, sehingga dapat disimpulkan bahwa bahwa sampel berasal dari populasi berdistribusi normal. Dari data hasil pretest dan posttest memenuhi kriteria pengujian karena keduanya berdistribusi normal.Berdasarkan uji-t diperoleh $\mathrm{t}$ hitung $>\mathrm{t}$ tabel yaitu $10>2,047$. Dengan demikian $\mathrm{HO}$ ditolak dan $\mathrm{Ha}$ diterima.Dapat disimpulkan bahwa ada perbedaan hasil belajar siswa sebelum dan sesudah perlakuan.
\end{abstract}

Kata Kunci: Keefektifan Belajar, Model CTL, Hasil Belajar

\begin{abstract}
This type of research was a quantitative research with pre-experimental design in the form of one group pretest-posttest design. The aimed of this study was to determine the effectiveness of the Contextual Teaching and Learning model on the mathematics learning outcomes of the fifth grade students of SD N 01 Rowosari Kendal. The sample were 25 students. Based on the calculation of the initial normality test using the Liliefors test, obtained $n=22$ and the real level $\alpha=0.05$, from the list of critical values of $L$ obtained Ltabel $=0.90$. Because Lhitung $<$ Label that $0.142<0.190$, then Ho accepted so that it can be concluded that the sample comes from the normal distribution population. Based on the calculation of the final data the posttest value was obtained Lhitung $=0.164$ with $n=22$ and the real level $\alpha=0.05$ from the list of critical $L$ values obtained Ltable $=0.190$, because Lhitung <Ltable is 0.082 $<0.173$ then Ho accepted, so it can be concluded that samples come from populations with normal distribution. From the pretest and posttest data, it fulfills the testing criteria because both are normally distributed. Based on the t-test, $\mathrm{t}$ count $>\mathrm{t}$ table is $10>2.047$. Thus $\mathrm{HO}$ rejected and $\mathrm{Ha}$ accepted. It can be concluded that there are differences in student learning outcomes before and after treatment.
\end{abstract}

Keywords: Learning Effectiveness, CTL Model, Learning Outcomes. 


\section{Pendahuluan}

Berdasarkan Permendiknas No.22 tahun 2006 tujuan dari pelajaran matematika adalah agar peserta didik memiliki kemampuan sebagai berikut: (1) Memahami konsep matematika, menjelaskan keterkaitan antar konsep dan mengaplikasikan konsep atau alogoritma, secara luwes, akurat, efisien, dan tepat, dalam pemecahan masalah; (2) Menggunakan penalaran pada pola dan sifat, melakukan manipulasi matematika dalam membuat generalisasi, menyusun bukti, atau menjelaskan gagasan dan pernyataan matematika; (3) Memecahkan masalah yang meliputi kemampuan memahami masalah, merancang model matematika, menyelesaikan model dan menafsirkan solusi yang diperoleh; (4) Mengomunikasikan gagasan dengan simbol, tabel, diagram, atau media lain untuk memperjelas keadaan atau masalah; dan (5) Memiliki sikap menghargai kegunaan matematika dalam kehidupan, yaitu memiliki rasa ingin tahu, perhatian, dan minat dalam mempelajari matematika, serta sikap ulet dan percaya diri dalam pemecahan masalah.

Persepsi bahwa matematika merupakan mata pelajaran yang dianggap paling sulit bagi sebagian siswa dibanding mata pelajaran lainya. Disebabkan beberapa faktor, salah satunya adalah kegiatan belajar mengajar matematika yang masih didominasi oleh pembelajaran konvensional. Adapun salah satu materi yang dianggap masih rendah tingkat pemahaman peserta didik dalam menguasai materinya adalah materi pecahan. Penyelesaian soal operasi hitung bilangan pecahan membutuhkan pemahaman konsep yang lebih sulit dibandingkan dengan operasi hitung bilangan lainnya, sehingga banyak siswa yang mengalami kesulitan dalam memahami operasi hitung bilangan. Peserta didik juga belum mengetahui konsep yang benar bagaimana cara menyelesaikan masalah operasi pecahan. Hal ini menjadikan peserta didik merasa enggan untuk belajar matematika lebih kritis dalam pemecahan masalah, sehingga peserta didik hanya pasif dan akan berpengaruh pada hasil belajar yang rendah.

Dari hasil wawancara yang dilakukan dikelas V SDN 01 Rowosari dengan guru kelas V pada tanggal 15 Desember 2018 menunjukkan bahwa 64\% siswa belum mencapai kriteria ketuntasan minimal (KKM). Rendahnya kemampuan siswa dibawah KKM disebabkan karena dalam proses pembelajaran siswa kurang antusias dalam mengikuti pelajaran matematika dan disamping itu guru masih menggunakan model yang kurang variatif.

Dari permasalahan di atas salah satu upaya untuk mengatasi masalah tersebut, maka guru harus mencoba memberikan alternatif model pembelajaran yang dapat mendorong aktivitas siswa dalam kegiatan belajar mengajar sehingga dapat meningkatkan hasil belajar siswa dengan menerapkan Model Contextual Teaching and Learning (CTL) karena model pembelajaran ini karena model CTL dapat memudahkan siswa memahami materi pembelajaran. CTL merupakan salah satu model pembelajaran yang berasosiasi dengan kurikulum berbasis kompetensi dan cukup relevan untuk diterapkan di sekolah (Zulaiha, 2016). Materi pembelajaran dengan model CTL disampaikan dengan mengaitkan dengan kehidupan sehari-hari serta meningkatkan kemampua siswa. Model pembelajaran CTL ini dapat menerapkan materi pecahan dengan baik. Materi pecahan merupakan materi pelajaran matematika yang sangat erat dengan kehidupan sehari-hari.

Pembelajaran CTL adalah konsep belajar yang membantu guru mengaitkan antara materi yang diajarkannya dengan situasi dunia nyata siswa dan mendorong siswa membuat hubungan antara pengetahuan yang dimilikinya dengan penerapannya dalam kehidupannya mereka sehari-hari. Pembelajaran CTL dapat dikatakan sebagai suatu pendekatan yang mengkui dan menunjukkan kondisi alamiah dari pengetahuan. Memalui hubungan didalam dan diluar ruang kelas, suatu pendekatan pembelajaran CTL menjadikan pengalaman yang lebih relevan dan berarti bagi siswa dalam membangun pengetahuan yang akan mereka terapkan dalam pembelajaran seumur hidup. Pembelajaran CTL menyajikan suatu konsep yang mengaitkan materi pelajaran yang dipelajari siswa dengan konteks dimana materi itu digunakan, serta berhubungan dengan bagaimana seseorang belajar atau cara siswa belajar.

Ngalimun (2014:162) mengatakan model CTL adalah suatu model pembelajaran yang dimulai dengan sajian atau Tanya jawab lisan(ramah, terbuka, negosiasi) yang terkait dengan 
dunia nyata kehidupan siswa (daily life modelling), sehingga akan terasa manfaat dari materi yang disajikan, motivasi belajar muncul, dunia pikiran siswa menjadi konkret, dan suasana menjadi kondusif (nyaman) dan menyenangkan. Thobroni (2012:7) juga berpendapat bahwa pembelajaran kontekstual yang merupakan salah satu pendekatan pembelajaran yang menekankan pentingnya lingkungan alamiah itu diciptakan dalam proses belajar agar kelas lebih "hidup" dan lebih "bermakna" karena siswa mengalami sendiri apa yang dipelajarinya. Bila pembelajaran kontekstual diterapkan dengan benar, diharapkan siswa akan terlatih untuk dapat menghubungkan apa yang diperoleh dikelas dengan kehidupan nyata yang ada di lingkungannya. Dalam kurikulum berbasis kompetensi, siswa akan dibawa tidak hanya masuk ke kawasan pengetahuan, tetapi juga sampai pada penerapan pengetahuan yang di dapatkannya melalui pembelajaran kontekstual. Tugas guru dalam kelas kontekstual adalah membantu siswa mencapai tujuan pembelajaran. Maksudnya, guru lebih banyak berurusan dengan strategi dari pada memberi informasi.

Sanjaya dalam Laila (2009:243) juga mengemukakan bahwa model pembelajaran CTL adalah suatu strategi pembelajaran yang menekankan kepada proses keterlibatan siswa secara penuh untuk dapat menemukan materi yang dipelajari dan menghubungkannya dengan situasi kehidupan nyata sehingga mendorong siswa untuk dapat menerapkannya dalam kehidupan mereka. Oleh karena itu, proses pembelajaran berlangsung alamiah yang mana siswa bekerja dan mengalami langsung, bukannya mentransfer pengetahuan dari guru ke siswa.

Penelitian yang relevan terdahulu yang dilakukan oleh Penelitian yang dilakukan oleh Desi Wulandari yang berjudul "Keefketifan pendekatan CTL terhadap hasil belajar IPA materi sumber daya alam kelas IV SD N 01 Wonosari". Hasil analisis statistik diketahui t-hitung $\geq \mathrm{t}-$ tabel terdapat nilai t-hitung $=4,707$ dan t-tabel $=1,728$ maka $\mathrm{Ha}$ diterima dan $\mathrm{Ha}$ ditolak. Sehingga model CTL efektif terhadap hasil belajar IPA materi sumber daya alam kelas IV SD N 01 Wonosari.

\section{Metode}

Dalam penelitin ini yang menjadi obyek penelitian yaitu kelas V SD N 01 Rowosari yang berjumlah 25 siswa. Desain/rancangan penelitian yang digunakan adalah Pre Eksperimental Design (nondesigns) karena desain ini belum merupakan sungguh-sungguh, karena masih terdapat belajar variabel luar yang ikut berpengaruh terhadap bentuknya variabel dependen. Bentuk Pre Eksperimental Design yang digunakan adalah bentuk One Group Pretest-Posttest Design pada desain ini terdapat pretest, sebelum diberi perlakuan. Desain ini dapat digambarkan seperti berikut:

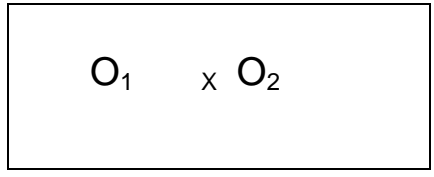

Gambar 1. Rancangan Penelitian

Keterangan:

$\mathrm{O}_{1}=$ nilai pretest (tes awal) sebelum diberi perlakuan

$\mathrm{O}_{2}=$ nilai posttest (tes terakhir) sesudah diberi perlakuan

$\mathrm{X}=$ pembelajaran dengan menggunakan model Group Investigation

Penelitian ini dilaksanakan di SDN 01 Rowosari, alasan memilih SDN 01 Rowosari sebagai tempat penelitian yaitu karena peneliti menemukan beberapa masalah berkaitan dengan hasil belajar peserta didik yang masih rendah sehingga peneliti bermaksud untuk memperbaikinya. Penelitian ini dilaksanakan pada semester genap tahun ajaran 2018/2019. 
Sugiyono (2015: 81) mengatakan teknik sampling adalah merupakan teknik pengambilan sampel. Untuk menentukan sampel yang akan digunakan. Teknik pengumpulan data yang digunakan dalam penelitian ini yaitu:

a. Tes

Metode ini digunakan untuk mengetahui hasil belajar siswa. Dalam metode tes yaitu tes objektif. Pada penelitian ini peneliti menggunakan bentuk tes pilihan ganda untuk mengukur hasil belajar mata pelajaran matematika materi pecahan kelas V SD N 01 Rowosari.

b. Wawancara

Peneliti melakukan penelitian pada siswa kelas V SDN 01 Rowosari dalam pembelajaran terfokuskan dalam pembelajaran matematika materi pecahan sehingga dapat dijadikan landasan dalam penelitian.

c. Dokumentasi

Metode dokumentasi yaitu mencari data mengenai hal-hal atau variabel yang berupa catatan, transkip, buku, surat kabar, majalah, prasasti, notulen rapat, lengger, agenda, dan sebagainya. Dalam penelitian ini metode dokumentasi digunakan untuk mendapatkan data-data yang diperlukan dalam penelitian seperti daftar nama siswa, nilai kognitif siswa dari kegiatan pembelajaran di kelas $\mathrm{V}$ SD Negeri 01 Rowosari kendal.

Analisis Instrumen Penelitian yang digunakan dalam penelitian ini antara lain:

a. Validitas soal

Untuk mengetahui validitas tes atau alat ukur yang digunakan dengan menggunakan rumus korelasi Product Moment dengan angka kasar sebagai berikut:

Rumus Korelasi Product Moment dengan angka kasar:

$$
r_{x y}=\frac{N \sum X Y-\left(\sum X\right)\left(\sum Y\right)}{\sqrt{\left(N \sum X^{2}-\left(\sum X\right)^{2}\right)\left(N \sum Y^{2}-\left(\sum Y\right)^{2}\right)}}
$$

(Arikunto, 2013:87)

Keterangan:

$r_{x y}=$ Koefisien korelasi variabel $X$ dan $Y$

$\mathrm{N}=$ Jumlah peserta tes

$\Sigma X=$ Jumlah dari rata-rata nilai ulangan

$\Sigma Y=$ Jumlah dari rata-rata nilai harian

$\Sigma X Y=$ Jumlah perkalian antara $X$ dan $Y$

Harga $r_{x y}$ yang diperoleh dibandingkan dengan $r_{\text {tabel }}$ product moment dengan taraf signifikan 5\%. Jika harga $r_{x y}>r_{\text {tabel }}$ maka korelasi signifikandan instrumen soal dinyatakan valid.Kemudian jika harga $r_{x y}<r_{\text {tabel }}$ maka korelasi tidak signifikan atau instrumen soal dinyatakan tidak valid.

Pada soal bentuk objektif skor untuk butir soal biasa diberikan 1 (bagi soal yang dijawab benar) dan 0 (bagi soal yang dijawab salah), sedangkan skor total selanjutnya didapat dari jumlah keseluruhan skor untuk semua butir soalnya. Butir soal yang valid kemudian digunakan untuk prestest maupun posttest. Dalam butir soal prestest maupun posttest semua butir soalnya mencakup butir soal yang ada pada uji instrumen.

\section{b. Reliabilitas Soal}

Arikunto (2013: 100) mengatakan "Suatu tes dapat dikatakan mempunyai tingkat kepercayaan yang tinggi jika tes tersebut dapat memberikan hasil yang tetap. Maka reliabilitas tes, berhubungan dengan ketetapan hasil tes". Untuk menguji reliabilitas instrumen tes digunakan rumus KR- 20 (Kuder Richardson). Harga $r_{11}$ dibandingkan dengan $r_{\text {tabel }}$ Product 
Moment Apabila $r_{\text {hitung }}<r_{\text {tabel }}$ maka instrumen tersebut reliabel atau dapat dipercaya (Arikunto, $2013: 115)$

Klasifikasi Reliabilitas :

1) Antara 0,800 sampai dengan $1,00=$ Realibilitas Sangat Tinggi

2) Antara 0,600 sampai dengan $0,800=$ Realibilitas tinggi

3) Antara 0,400 sampai dengan $0,600=$ Realibilitas cukup

4) Antara 0,200 sampai dengan $0,400=$ Realibilitas rendah

5) Antara 0,00 sampai dengan $0,200=$ Realibilitas Sangat Rendah

c. Taraf Kesukaran

Soal yang baik adalah soal yang tidak terlalu mudah dan tidak terlalu sukar, soal yang terlalu mudah tidak memotivasi peserta didik untuk meningkatkan usaha pemecahannya, sedangkan soal yang terlalu sukar akan menyebabkan peserta didik menjadi putus asa dan menjadi tidak semangat untuk mencoba lagi karena di luar jangkauannya. Rumus yang digunakan adalah sebagai berikut.

$$
P=\frac{B}{J S}
$$

(Arikunto, 2013: 223).

Keterangan:

$\mathrm{P}=$ Indeks Kesukaran

$\mathrm{B}$ = Banyaknya peserta didik yang menjawab soal itu dengan betul

$\mathrm{J}_{\mathrm{S}}=$ Jumlah seluruh peserta didik peserta tes

Kriteria indeks kesukaran diklasifikasikan sebagai berikut :

Soal dengan $P$ 0,00 sampai 0,30 adalah soal sukar

Soal dengan $P$ 0,30 sampai 0,70 adalah soal sedang

Soal dengan $P$ 0,70 sampai 1,00 adalah soal mudah

(Arikunto, 2013: 225).

d. Daya Pembeda

Arikunto (2013: 226) mengatakan "Daya pembeda soal adalah kemampuan sesuatu soal untuk membedakan antara peserta didik yang berkemampuan tinggi dengan peserta didik yang berkemampuan rendah.

Rumus Daya Pembeda :

$$
D=\frac{B_{A}}{J_{A}}-\frac{B_{B}}{J_{B}}=P_{A}-P_{B}
$$

(Arikunto, 2013: 228-229).

Keterangan:

$\mathrm{D}=$ Jumlah peserta tes

$J_{A}=$ Banyaknya peserta kelompok atas

$J_{B}=$ Banyaknya peserta kelompok bawah

$\mathrm{B}_{\mathrm{A}}=$ Banyaknya peserta kelompok atas yang menjawab soal itu dengan benar

$\mathrm{B}_{\mathrm{B}}=$ Banyaknya peserta kelompok bawah yang menjawab soal itu dengan benar

$\mathrm{B}_{\mathrm{B}}=$ Banyaknya peserta kelompok bawah yang menjawab soal itu dengan benar

$\mathrm{P}_{\mathrm{A}}=\frac{\mathrm{B}_{A}}{\mathrm{I}_{A}}=$ Proporsi peserta kelompok atas yang menjawab benar

$\mathrm{P}_{\mathrm{B}}=\frac{\mathrm{B}_{B}}{\mathrm{~J}_{B}}=$ Proporsi peserta kelompok bawah yang menjawab benar 
Klasifikasi daya pembeda:

D : $0,00-0,20=$ jelek (poor)

D : $0,20-0,40=$ cukup (satisfactory)

D : $0,40-0,70=$ baik (good)

D : $0,70-1,00=$ baik sekali (exellent)

$D$ : negatif, semuanya tidak baik. Jadi butir soal yang bernilai $D$ negatif sebaiknya tidak dipakai

Teknik Aanalisis Data

(Arikunto, 2013: 232).

Langkah- langkah dalam analisis data adalah sebagai berikut:

a. Analisis data awal

1) Uji Normalitas

Uji normalitas digunakan untuk mengetahui apakah sample kedua kelompok berasal dari populasi berdistribusi normal atau tidak, untuk menguji normalitas ini digunakan uji lilliefors. Misalkan sample acak dengan menggunakan $\mathrm{x}_{1}, \mathrm{x}_{2}, \ldots ., \mathrm{x}_{\mathrm{n}}$.

Berdasarkan sample ini akan diuji hipotesis nol dan hipotesis alternatifnya, yaitu :

$\mathrm{H}_{0}$ : Sampel tidak berasal dari populasi yang berdistribusi normal.

$\mathrm{H}_{\mathrm{a}}$ : Sampel berasal dari populasi yang berdistribusi normal.

Adapun langkah- langkah untuk menguji kenormalan suatu sample adalah:

a) Pengamatan $x_{1}, x_{2, \ldots . . .} x_{n}$ dijadikan bilangan baku $z_{1}, z_{2,} \ldots, z_{n}$ dengan menggunakan rumus $Z_{i}=\frac{X i-x}{s}$

Keterangan:

$\mathrm{Z}_{\mathrm{i}} \quad$ : Bilangan baku

$\mathrm{X}_{\mathrm{i}} \quad$ : Data dari sampel

$X$ : Rata-rata

S : Simpangan baku

b) Untuk tiap bilangan baku ini menggunakan daftar distribusi normal baku, kemudian dihitung peluang.

$F\left(Z_{i}\right)=P\left(Z \leq Z_{i}\right)$

Selanjutnya dihitung proporsinya $z_{1}, z_{2}, \ldots . ., Z_{n}$ yang lebih kecil atau sama dengan $Z_{i}$. Jika proporsinya ini dinyatakan oleh $\mathrm{S}\left(\mathrm{Z}_{\mathrm{i}}\right) \cdot \mathrm{S}\left(\mathrm{Z}_{\mathrm{i}}\right)=\frac{\text { banyaknyaz } 1_{2} z 2_{s}, z n \leq z i}{n}$

a) Hitung selisih $\mathrm{F}(\mathrm{Zi})-\mathrm{S}(\mathrm{ZI})$, terus tentukan harga mutlaknya.

b) Ambil harga yang paling besar diantara harga-harga mutlak selisih tersebut.

c) Bandingkan $L_{0}<L_{\text {label }}$ Maka $H_{0}$ diterima bahwa sampel dari data yang berdistribusi normal dan menentukan kesimpulan.

Jika $\mathrm{L}_{0}<\mathrm{L}_{\text {label }}$ Maka $\mathrm{H}_{0}$ diterima bahwa sampel dari data yang berdistribusi normal. Jika $L_{0}>L_{\text {label, }}$ maka $H_{0}$ ditolak bahwa sampel dari data yang berdistribusi tidak normal ( $L_{\text {label }}$ diperoleh dari tabel lillefors.

b. Analisis Data Akhir

1) Uji T

Data ini digunakan untuk menguji hipotesis sehingga dapat diambil suatu kesimpulan. Adapun rumus Uji t yang digunakan adalah sebagai berikut:

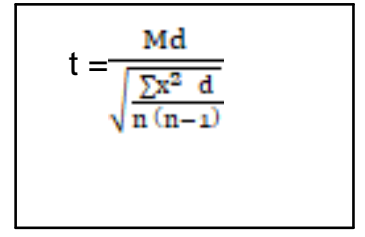

Keterangan:

$\mathrm{t}=$ Uji Banding T Satu Sampel

$\mathrm{Md}=$ Mean Dari Perbedaan Prestest Dan Postest

$\mathrm{X}=$ Deviasi Masing-Masing Subjek 
$\sum \mathrm{X}^{2} \mathrm{D}=$ Jumlah Kuadrat Devias

$\mathrm{n}=$ Subjek Pada Sampel

Kriteria pengujian:

\begin{tabular}{|l|}
$\mathrm{H}_{0}=\mathrm{O}_{1}>\mathrm{O}_{2}<\mathrm{KKM}$ \\
$\mathrm{H}_{\mathrm{a}}=\mathrm{O}_{1} \leq \mathrm{O}_{2} \geq \mathrm{KKM}$ \\
\hline
\end{tabular}

$\mathrm{H}_{0}$ : Hasil Pretest dan Postest Tidak efektif.

$\mathrm{H}_{\mathrm{a}}$ : Hasil Pretest dan Posttest efektif.

Kriteria pengujian $\mathrm{H}_{0}$ ditolak $\left(\mathrm{H}_{\mathrm{a}}\right.$ diterima) jika $\mathrm{t}_{\text {hitung }}>\mathrm{t}_{\text {tabel }}$ melihat harga $\mathrm{t}_{\text {tabel }}$ digunakan $\mathrm{db}=\mathrm{N}-1$ dengan taraf kesalahan $5 \%$.

\section{Hasil Dan Pembahasan}

Data yang diperoleh dalam penelitian ini berdasarkan hasil pretest dan posttest. Teknik pretest-posttest yang digunakan bertujuan untuk mengetahui keefektifan model CTL terhadap hasil belajar matematika materi pecahan siswa kelas $\mathrm{V}$ pada ranah kognitif. Pretest dilaksanakan pada awal pertemuan dan posttest dilaksanakan pada akhir penelitian setelah menggunakan model Contexyual Teaching and Learning (CTL) dalam kegiatan belajar mengajar. Hasil dari nilai pretest dan posttest

siswa diolah dan diperoleh nilai sebagai berikut :

Tabel 1. Rekapitulasi Nilai Pretest dan Posttest

\begin{tabular}{ccc}
\hline Keterangan & Nilai Pretest & Nilai Posttest \\
\hline Nilai Tertinggi & 75 & 85 \\
Nilai Terendah & 35 & 45 \\
Rata-rata & 54,7 & 63,8 \\
\hline
\end{tabular}

Dari hasil Tabel 1 dapat diketahui bahwa hasil belajar siswa kelas $\mathrm{V}$ pada mata pelajaran Mtematika materi pecahan dengan menggunakan model $C T L$, diperoleh nilai rata-rata pretest sebesar 54,7 dengan nilai tertinggi 75 dan nilai terendah 35 . Nilai rata-rata posttest sebesar 63,8 dengan nilai tertinggi 85 dan nilai terendah 45. Data pada tabel setelah menggunakan model CTL dalam kegiatan belajar mengajar, nilai rata-rata hasil belajar siswa mengalami peningkatan. Rata-rata nilai posttest lebih besar daripada nilai pretest dengan rata-rata nilai posttest yang diperoleh siswa kelas V SD N 01 Rowosari Kendal.

1) Uji Normalitas awal (pretest)

Uji Normalitas Awal (Pretest) Uji normalitas awal digunakan untuk mengetahui apakah nilai pretest berasal dari sampel yang berdistribusi normal atau tidak. Uji normalitas menggunakan rumus Liliefors dengan ketentuan bahwa kelompok berdistribusi normal jika memenuhi kriteria < yang diukur pada taraf signifikasi 0,05.

Tabel 2. Uji Normalitas awal Pretest

\begin{tabular}{cccc}
\hline Nilai & $\mathrm{L}_{0}$ & $\mathrm{~L}_{\text {tabel }}$ & Keterangan \\
\hline pretest & 0,142 & 0,190 & Berdistribusi Normal \\
\hline
\end{tabular}


Berdasarkan Tabel 2 hasil peritungan nilai pretest dengan jumlah $\mathrm{n}$ sebanyak 22 dan taraf signifikan 0,05 diperoleh $L_{\text {tabel }}$ sebesar 0,190. Karena $L_{0}<L_{\text {tabel }}$ yaitu 0,142 $<0,190$ maka $\mathrm{H}_{0}$ diterima. Artinya dapat disimpulkan bahwa sampsampel berdistribusi normal.

2) Uji Normalitas Akhir (posttest)

Uji normalitas akhir digunakan untuk mengetahui apakah nilai posttest berasal dari sampel berdistribusi normal atau tidak. Uji normalitas menggunakan rumus liliefors dengan ketentuan bahwa kelompok berdistribusi normal jika memenuhi kriteria $L_{o}<L_{\text {tabel }}$ yang diukur pada taraf signifikan 0,05 .

Tabel 3. Uji normalitas akhir (posttest)

\begin{tabular}{llll}
\hline Nilai & $\mathrm{L}_{0}$ & $\mathrm{~L}_{\text {tabel }}$ & Keterangan \\
\hline Postest & 0,164 & 0,190 & Berdistribusi Normal \\
\hline
\end{tabular}

Berdasarkan Tabel 3 hasil perhitungan nilai posttest dengan jumlah $\mathrm{n}$ sebanyak 22 dengan taraf signifikan 0,05 diperoleh $L_{\text {tabel }}$ sebesar 0,190 . Karena $L_{0}<L_{\text {hitung }}$ yaitu $0,190<$ 0,164 maka $\mathrm{H}_{0}$ diterima. Artinya dapat disimpulkan bahwa sampel berdistribusi normal.

3) Perhitungan Uji t

Tabel 4. Perhitungan Uji-t

\begin{tabular}{cccc}
\hline Responden & $\mathrm{t}_{\text {hitung }}$ & $\mathrm{T}_{\text {tabel }}$ & Kesimpulan \\
\hline 22 & 10 & 2,047 & $\mathrm{H}_{0}$ ditolak \\
\hline
\end{tabular}

Berdasarkan Tabel 4 menunjukkan bahwa $t_{\text {hitung }}$ lebih besar dari pada nilai $\mathrm{t}_{\text {tabel }}$ maka $\mathrm{H}_{0}$ ditolak. Sehingga dapat disimpulkan terdapat perbedaan yang signifikan antara rata-rata nilai pretest dengan nilai posttest. Temuan hasil penelitian ini sesuai dengan temuan sebelumnya. Temuan penelitian tersebut antara lain sebagai berikut: Aryani (2013) menyatakan model pembelajaran CTL dapat meningkatkan aktivitas dan hasil belajar IPA, dampaknya siswa yang awalnya kurang aktif menjadi aktif dalam mengikuti pembelajaran, Ratih (2014) menyatakan pendekatan CTL melalui permodelan media sederhana berpengaruh terhadap hasil belajar matematika bisa membuat siswa lebih aktif dalam proses pembelajaran, siswa lebih berani mengungkapkan pendapatnya sendiri dan siswa mendapatkan ide-ide yang baru, Penelitian oleh Suarjana (2018) menunjukkan bahwa terdapat perbedaan hasil belajar matematika antara siswa yang dibelajarkan menggunakan model pembelajaran CTL berorientasi Tri kaya Parisudha dengan kelompok siswa yang tidak dibelajarkan menggunakan model pembelajaran CTL berorientasi Tri kaya Parisudha pada siswa kelas III di Gugus III semester II Kecamatan Banjar Kabupaten Buleleng tahun pelajaran 2017/2018

\section{Simpulan dan Saran}

Penelitian ini dilakukan di SD N 01 Rowosari Tahun Pelajaran 2018/2019 yang dilaksanakan pada semester genap pada siswa kelas $\mathrm{V}$ dengan jumlah 25 siswa. Berdasarkan wawancara dengan guru kelas V SD N 01 Rowosari yaitu Sri Wiji Astuti S.Pd., bahwa respon siswa dalam pembelajaran kurang antusias. Siswa hanya diam jika diberi kesempatan bertanya. Kendala pada pembelajaran yang ada siswa kurang antusias ketika pembelajaran matematika berlangsung. Tujuan utama menggunakan model Contextual Teaching and Learning saat proses pembelajaran yaitu untuk memudahkan siswa dalam memahami pelajaran matematika khususnya materi pecahan.

Berdasarkan hasil penelitian yang dilakukan di SD N 01 Rowosari dapat disimpulan bahwa Setelah dilakukan analisis data nilai hasil belajar pada nilai pengetahuan (kognitif) 
dengan $\mathrm{N}=22$ jadi $\mathrm{db}=\mathrm{N}-1=21$ yang diperoleh thitung $=8,699$ dengan taraf signifikan $5 \%$ didapat nilai ttabel $=2,059$. Karena thitung $10>$ ttabel 2,047 maka Ha diterima sehingga model Contextual Teaching and Learning (CTL) efektif terhadap hasil belajar siswa kelas V SD N 01 Rowosari.

Berdasarkan perhitungan hasil ketuntasan belajar siswa sebelum diberi perlakuan (pretest) tanpa menggunakan model Contextual Teaching and Learning (CTL) terdapat 5 siswa yang tuntas dengan presentase $22 \%$ dan sebanyak 17 siswa belum tuntas dengan presentase 88\%. Sedangkan setelah diberi perlakuan (posttest) dengan menggunakan model Contextual Teaching and Learning (CTL), siswa yang tuntas meningkat menjadi 9 siswa dengan presentase mencapai $40 \%$, namun masih ada 13 siswa yang belum tuntas dengan presentase $60 \%$. Setelah melakukan analisis uji t, kesimpulan model Contextual Teaching and Learning (CTL) ada pengaruh terhadap hasil belajar matematika materi pecahan karena presentase klasikal posttest siswa lebih dari $22 \%$ yaitu presentase klasikal posttest mencapai $40 \%$ dan indikatornya dikatakan berhasil.

Dari hasil penelitian, maka saran yang dapat diajukan adalah Sebagai berikut : 1) Model Contextual Teaching and Learning (CTL) dapat digunakan dalam pembelajaran matematika di sekolah sebagai model pembelajaran yang inovatif, 2) Guru diharapkan mengembangkan kretifitas dalam proses pembelajaran dan menggunkan model dan media sebagai rangsangan untuk memberikan dorongan siswa dalam meningkatkan hasilbelajar.

\section{Daftar Rujukan}

Alizamar. 2016. Teori Belajar dan Pembelajaran; Impleemtasi dalam Bimbingan Kelompok Belajar di Perguruan Tinggi. Yogyakarta: Media Akademi.

Al-Tahabani, TIB. 2017. Mendesain Model Pembelajaran Inofatif, Progersif, dan Kontekstual. Jakarta: Kencana.

Arikunto, Suharsimi. 2013. Prosedur Penelitian. Jakarta. Rineka Cipta 2013.

Aryani, Ni Kt. Sri \& I Nym Murda, I. G. A. Tri Agustiana. 2013. "Penerapan Model Pembelajaran CTL (Contectual Teaching Learning) Berbantuan Media Gambar Untuk Meningkatkan Aktivitas Dan Hasil Belajar Ipa Siswa Kelas V". MIMBAR PGSD Undiksha Vol 1, No 1 (2013)

Chaqiqi, Aulia. 2012. Pengaruh Pendekatan Contextual Teaching and Learning (CTL) terhadap Hasil Belajar mata pelajaran Matematika materi garis dan sudut pada Siswa Kelas VII DI SMPN 16 Surabaya. Universitas Negeri Surabaya Kampus Lidah Wetan.

Depdiknas. 2001. Kamus Besar Bahasa Indonesia. Jakarta: Balai Pustaka.

Hilman, Latief. 2014. Pengaruh Pembelajaran Kontekstual terhadap Hasil Belajar. Universitas Pendidikan Indonesia.

Hasibuan, HMI. 2014. Model Pembelajaran CTL (Contextual Teaching And Learning. Logaritma Vol. II.

Husmawati. 2016. Peningkatan hasil belajar melalui pendekatan kontekstual dengan menggunakan media video SMA N 1 Leumbah Seulawah. Halaman 24-25.

Ratih. 2014. "Pengaruh Pendekatan Contextual Teaching And Learning (CTL) Melalui Pemodelan Media Sederhana Terhadap hasil Belajar Matematika Siswa Kelas V SD 
Gugus III Kecamatan Gianyar". E-Journal Mimbar PGSD Universitas Pendidikan Ganesha, Volume 2, No 1

Septian, ID. 2016. Keefektikan Model Teaching and Learning terhadap Aktivitas dan Hasil Belajar Kimia siswa SMA N 02 Demak. Fakultas Matematika Dan Ilmu Pengetahuan Alam (Ipa) Universitas Negeri Semarang.

Suarjana, I Made, I Ketut Dibia, Ni Luh Ayu Sariani. 2018. Pengaruh Model Pembelajaran CTL Berorientasi Tri Kaya Parisudha terhadap Hasil Belajar Matematika Siswa Kelas III. International Journal of Elementary Education. Volume 2, Number 3, pp. 131-137.

Sugiyono. 2015. Metode Peneletian Kuantitatif, Kualitatif, dan R\&D. Bandung: Alfabeta cv.

Thobroni, M. 2017. Belajar dan Pembelajaran. Yogyakarta: Ar-Ruzz Media.

Yumrotun, Siti. 2018. Pengaruh Model Problem Based Learning terhadap Keaktifan dan Hasil Belajar Matematika materi pecahan Siswa Kelas IV SD N 01 Sidomulyo Kendal. Program Studi Pendidikan Guru Sekolah Dasar Fakultas Ilmu Pendidikan Universitas Pgri Semarang.

Zulaiha, Siti. 2016. Pendekatan Contextual Teaching And Learning (CTL) Dan Implementasinya Dalam Rencana Pembelajaran PAI MI. Belajea: Jurnal Pendidikan Islam vol. 1, no 01. 